\title{
From canals to the coast: dissolved organic matter and trace metal composition in rivers draining degraded tropical peatlands in Indonesia
}

\author{
Laure Gandois $^{1}$, Alison M. Hoyt ${ }^{2, a}$, Stéphane Mounier ${ }^{3}$, Gaël Le Roux ${ }^{1}$, Charles F. Harvey ${ }^{2,4}$, Adrien Claustres ${ }^{1}$, \\ Mohammed Nuriman ${ }^{5}$, and Gusti Anshari ${ }^{5}$ \\ ${ }^{1}$ EcoLab, Université de Toulouse, CNRS, INPT, UPS, Toulouse 31326, France \\ ${ }^{2}$ Department of Civil and Environmental Engineering, Massachusetts Institute of Technology, Cambridge, MA 01239, USA \\ ${ }^{3}$ PROTEE, Université de Toulon, 83957, La Garde, France \\ ${ }^{4}$ Center for Environmental Sensing and Modeling, Singapore-MIT Alliance for Research and Technology, Singapore \\ ${ }^{5}$ Soil Science Department, Universitas Tanjungpura (UNTAN), Pontianak, \\ West Kalimantan, Indonesia \\ apresent address: Max Planck Institute for Biogeochemistry, 07745 Jena, Germany
}

Correspondence: Alison M. Hoyt (ahoyt@bgc-jena.mpg.de)

Received: 28 June 2019 - Discussion started: 12 August 2019

Revised: 19 January 2020 - Accepted: 29 January 2020 - Published: 8 April 2020

\begin{abstract}
Worldwide, peatlands are important sources of dissolved organic matter (DOM) and trace metals (TMs) to surface waters, and these fluxes may increase with peatland degradation. In Southeast Asia, tropical peatlands are being rapidly deforested and drained. The blackwater rivers draining these peatland areas have high concentrations of DOM and the potential to be hotspots for $\mathrm{CO}_{2}$ release. However, the fate of this fluvial carbon export is uncertain, and its role as a trace metal carrier has never been investigated. This work aims to address these gaps in our understanding of tropical peatland DOM and associated elements in the context of degraded tropical peatlands in Indonesian Borneo. We quantified dissolved organic carbon and trace metal concentrations in the dissolved and fine colloidal $(<0.22 \mu \mathrm{m})$ and coarse colloidal $(0.22-2.7 \mu \mathrm{m})$ fractions and determined the characteristics $\left(\delta^{13} \mathrm{C}\right.$, absorbance, fluorescence: excitationemission matrix and parallel factor - PARAFAC - analysis) of the peatland-derived DOM as it drains from peatland canals, flows along the Ambawang River (blackwater river) and eventually mixes with the Kapuas Kecil River (whitewater river) before meeting the ocean near the city of Pontianak in West Kalimantan, Indonesia. We observe downstream shifts in indicators of in-stream processing. An increase in the $\delta^{13} \mathrm{C}$ of dissolved organic carbon (DOC), along with an
\end{abstract}

increase in the $\mathrm{C} 1 / \mathrm{C} 2$ ratio of PARAFAC fluorophores, and a decrease in SUVA (specific UV absorbance) along the continuum suggest the predominance of photo-oxidation. However, very low dissolved oxygen concentrations also suggest that oxygen is quickly consumed by microbial degradation of DOM in the shallow layers of water. Blackwater rivers draining degraded peatlands show significantly higher concentrations of $\mathrm{Al}, \mathrm{Fe}, \mathrm{Pb}, \mathrm{As}, \mathrm{Ni}$ and $\mathrm{Cd}$ compared to the whitewater river. A strong association is observed between DOM, Fe, As, $\mathrm{Cd}$ and $\mathrm{Zn}$ in the dissolved and fine colloid fraction, while $\mathrm{Al}$ is associated with $\mathrm{Pb}$ and $\mathrm{Ni}$ and present in a higher proportion in the coarse colloidal fraction. We additionally measured the isotopic composition of lead released from degraded tropical peatlands for the first time and show that $\mathrm{Pb}$ originates from anthropogenic atmospheric deposition. Degraded tropical peatlands are important sources of DOM and trace metals to rivers and a secondary source of atmospherically deposited contaminants. 


\section{Introduction}

Most Southeast Asian tropical peatlands developed as domes beneath ombrotrophic peat swamp forests (Page et al., 2006; Cobb et al., 2017). They store at least $68.5 \mathrm{Pg} \mathrm{C}$, or $15 \%-$ $19 \%$, of the global peat carbon stocks (Dargie et al., 2017; Lähteenoja et al., 2009; Page et al., 2011). They have experienced widespread degradation as a result of deforestation, conversion to agriculture and drainage, which all accelerated in the late 2000s. This abrupt change in land use, and corresponding lowering of the water table, has led to subsidence and a massive release of carbon from peatlands to the atmosphere due to enhanced aerobic decomposition of organic matter from the drained peat. Extensive work has focused on quantifying the resulting $\mathrm{CO}_{2}$ fluxes (Couwenberg et al., 2010; Jauhiainen et al., 2012; Miettinen et al., 2017; Hoyt et al., 2019) and land surface subsidence (e.g. Hooijer et al., 2012; Carlson et al., 2015).

Drainage canals are dug in forested peatlands for multiple reasons: first as a mechanism to transport timber out of the peatland during deforestation and later to lower the water table, making the land suitable for agriculture. These peatland drainage canals channel water from the peatlands to surrounding surface waters. The resulting fluvial export of dissolved organic matter (DOM) has been recognized as an important component of the carbon budget of tropical peatlands that could increase with deforestation and peatland exploitation (Moore et al., 2011; Gandois et al., 2013). Indonesia alone contributes over $10 \%$ of the global riverine dissolved organic carbon (DOC) input into the ocean (Baum et al., 2007), as a result of both high peatland coverage and high precipitation rates. This proportion is likely to increase with rapid peatland conversion to agriculture, which destabilizes long-term peat $\mathrm{C}$ stocks (Moore et al., 2013).

Another implication of DOM transfers from peatlands to surface water is the transport of associated elements, especially trace metals (TMs). Tropical peatlands in Southeast Asia are mainly ombrotrophic systems, which receive critical nutrients through atmospheric deposition, and serve as a sink for atmospheric pollutants (Weiss et al., 2002). Northern peatlands have been shown to constitute a source of major and trace elements to surface waters (Rothwell et al., 2007; Broder and Biester, 2017; Jeremiason et al., 2018). This has important implications: as a result of colloidal association between peatland-derived organic molecules and $\mathrm{Fe}$, northern peatlands are responsible for a significant transfer of $\mathrm{Fe}$ to the Atlantic Ocean (Krachler et al., 2010, 2012). In the UK, peat degradation and erosion have led to the dispersion of lead into watersheds, which previously accumulated through atmospheric deposition over decades (Rothwell et al., 2008). Although drainage of tropical peatlands is occurring at a rapid rate across Southeast Asia, to our knowledge no data are available on trace metal release in blackwater rivers draining tropical peatlands.
Blackwater rivers draining peatlands (as defined in Alkhatib et al., 2007) also have the potential to be hotspots of fluvial carbon degassing (Müller et al., 2015; Wit et al., 2015). By measuring $p \mathrm{CO}_{2}$ in Indonesian and Malaysian blackwater rivers, Wit et al. (2015) estimated that $53 \%$ of DOC entering surface waters was converted to $\mathrm{CO}_{2}$, which is similar to global averages for inland waters. In contrast, blackwater river measurements and incubations by Martin et al. (2018) found that a smaller proportion of DOC was processed in rivers. Rixen et al. (2008) also found that a large proportion of the DOM was resistant to decomposition in a laboratory incubation study. These studies have focused on $\mathrm{CO}_{2}$ measurements and incubations to assess the potential for DOM processing.

Monitoring both isotopic and optical characteristics of DOM composition in canals and rivers can provide complementary information on the extent of in-stream processing of fluvial carbon and potential emission of greenhouse gases (GHGs) to the atmosphere. Qualitative evaluation of in-stream DOM transformation by UV light and microbial processes can be performed using isotopic and optical characterization of DOM. The stable isotope signature of DOM is both an indicator of its origin (Hood et al., 2005; Barber et al., 2017) as well as transformation processes. Lalonde et al. (2014) assessed photochemical processing of DOM in major rivers worldwide and found that it caused an increase in the $\delta^{13} \mathrm{C}$ of DOM of $0.5 \%$ o to $2.3 \%$. Similarly, microbial processing is also expected to lead to an increase in the $\delta^{13} \mathrm{C}$ of DOM. Optical properties of DOM are also sensitive indicators of DOM processing (Spencer et al., 2009; Harun et al., 2015; Hansen et al., 2016). However, in contrast to the $\delta^{13} \mathrm{C}$ of DOM, which is similarly enriched by both microbial processing and photo-oxidation, the optical properties of DOM change in opposite directions in response to microbial processing or photo-oxidation. Microbial processing is generally found to increase the aromaticity of DOM by selective processing of less aromatic molecules, while photooxidation tends to decrease aromaticity because of selective photo-oxidation of aromatic moieties (Spencer et al., 2009; Hansen et al., 2016).

In summary, although there has been an increase in efforts to quantify DOC exports from tropical peatlands, our complementary understanding of the transfer of associated elements and in-stream processing of DOM remains limited. This work aims to address these gaps in our understanding of the composition and evolution of tropical peatland DOM and how it could act as a carrier of trace metals to surface waters in the context of highly degraded tropical peatlands in Indonesia. We characterize the quality of the peatlandderived DOM and trace metals as they drain from peatland canals, flow along blackwater rivers and eventually mix with a whitewater river before meeting the ocean. We assess spatial and seasonal changes in the organic matter quality and document changes in DOM composition due to transport, mixing and processing. We also assess blackwater river trace 
metal release to surface waters, analyzing trace metal concentrations and the isotopic composition of lead released from degraded tropical peatlands for the first time.

\section{Material and methods}

\subsection{Study area}

The study area is located in West Kalimantan, Indonesia, near the city of Pontianak $\left(0.09^{\circ} \mathrm{N}, 109.24^{\circ} \mathrm{E}\right)$ on the island of Borneo (Fig. 1). The climate is humid equatorial, with $2953 \pm 564 \mathrm{~mm}$ of rainfall and a mean annual temperature of $27^{\circ} \mathrm{C}(1985-2017$ data). The average monthly rainfall ranges from $170 \pm 126 \mathrm{~mm}$ (August) to $349 \pm 98 \mathrm{~mm}$ (November). The highest rainfall is measured from October to January. The mean rainfall is $274 \pm 123 \mathrm{~mm}$ for January and $199 \pm 106 \mathrm{~mm}$ for June (Fig. S1 in the Supplement). The study focused on the Ambawang River, which flows into the Landak River, which in turn flows into Kapuas Kecil River. It is a blackwater river draining a watershed (approximatively $706 \mathrm{~km}^{2}$ ) entirely covered with peatlands. This river was selected to represent water of exclusively peatland origin. All peatlands in the sampling area have been drained and converted to agriculture. Current land use consists of small-scale rubber plantations, secondary forest, oil palm plantations and human settlements.

\subsection{Sample collection and treatment}

Two sampling campaigns were conducted in June 2013 (drier period) and January 2014 (wetter period). Using a boat, samples were collected in the center of the river, from the origin of the Ambawang River (BR - blackwater river site) to its downstream confluence with the Landak and Kapuas Kecil (WR - whitewater river site). Whitewater river samples were collected upstream of the confluence with the whitewater river (WRu - whitewater river upstream). Drainage canals (DC) flowing into the blackwater river were also sampled during the second sampling campaign (Fig. 1). In January 2014, a rain collector was installed on the roof of the Pontianak's meteorological station to collect rain samples for lead isotopic analysis. In situ parameters $(\mathrm{pH}$, conductivity and dissolved oxygen) were measured using a multiparameter probe (WTW, Germany). Depth profiles of dissolved oxygen in the blackwater river were also measured with an oxygen microelectrode (MI-730 dip-type micro-oxygen electrode and O2-ADPT adapter; Microelectrodes, Inc., Bedford, NH, USA). Frequent calibration was performed with a zero-oxygen solution and distilled water equilibrated to ambient oxygen concentrations, where temperature was carefully monitored. To create the zero-oxygen solution, $1 \mathrm{~g}$ of sodium sulfite $\left(\mathrm{Na}_{2} \mathrm{SO}_{3}\right)$ and a few crystals $(\sim 1 \mathrm{mg})$ of cobalt chloride $\left(\mathrm{CoCl}_{2}\right)$ were dissolved in $1 \mathrm{~L}$ of distilled water. For measurements of additional parameters, a larger volume of water was collected for further analysis. Samples were filtered immediately following collection on the boat using a portable peristaltic pump (Geotech, USA) and prebaked $\left(5 \mathrm{~h}, 450^{\circ} \mathrm{C}\right)$ and pre-weighed $\mathrm{GF} / \mathrm{F}$ Whatman filters $(0.7 \mu \mathrm{m})$; stored in glass bottles for DOC, $\delta^{13} \mathrm{C}$-DOC and optical properties of DOM analysis; and acidified with $\mathrm{HCl}$ for DOC and $\delta^{13}$ C-DOC. Samples were filtered with cellulose acetate filters $(0.22 \mu \mathrm{m})$, acidified with $\mathrm{HNO}_{3}$, and stored in polypropylene vials for analysis of major nutrients and trace elements. DOC analysis was repeated on the cellulose acetate samples, and DOC concentrations did not differ significantly based on filtration at 0.2 or $0.7 \mu \mathrm{m}$. In January 2014 , at selected sites (eight), samples were first filtered with GF/D filters $(2.7 \mu \mathrm{m})$ to assess to the coarse colloidal fraction of trace metals and DOC.

\subsection{Sample analysis}

Non-purgeable organic carbon (NPOC, referred to hereafter as DOC) was analyzed on filtered samples after acidification to $\mathrm{pH} 2(\mathrm{HCl})$ with a TOC-V CSH analyzer (Shimadzu, Japan), with a quantification limit of $1 \mathrm{mg} \mathrm{L}^{-1}$. Major cations and anions were analyzed using high-performance liquid chromatography (HPLC; Dionex, USA). The quantification limit was $0.5 \mathrm{mg} \mathrm{L}^{-1}$ for chloride, nitrate and sulfates and $0.025 \mathrm{mg} \mathrm{L}^{-1}$ for ammonium, potassium, magnesium and calcium. Certified material (ion 915 and ion 96.4, Environment and Climate Change Canada, Canada) was included in the analytical loop, and recovery was $>95 \%$ of the certified value. For trace element analysis, samples were acidified with ultrapure $\mathrm{HNO}_{3}$ prior to inductively coupled plasma mass spectrometry (ICP-MS; 7500ce, Agilent Technologies) analysis. ${ }^{115}$ In was used as an internal standard. SLRS-4 (river water certified for trace elements) was used as a reference material on every run and accuracy (recovery $>95 \%$ ) was checked. Determination limits were $<0.5 \mu \mathrm{g} \mathrm{L}^{-1}$ for $\mathrm{Fe}$ and $\mathrm{Al} ;<0.05 \mu \mathrm{g} \mathrm{L}^{-1}$ for $\mathrm{Ni}, \mathrm{Cu}$ and $\mathrm{Zn}$; and $<0.005 \mu \mathrm{g} \mathrm{L}^{-1}$ for $\mathrm{Cd}$ and $\mathrm{Pb}$. $\mathrm{Pb}$ isotope ratios $\left({ }^{206} \mathrm{~Pb} /{ }^{207} \mathrm{~Pb} ;{ }^{208} \mathrm{~Pb} /{ }^{206} \mathrm{~Pb}\right)$ in water samples were analyzed using high-resolution ICP-MS (Thermo Element II XR; OMP service ICP-MS, Toulouse, France). Measurements were corrected for mass bias using individual sample bracketing with certified and adequately diluted NIST NBS981 (100 to $500 \mathrm{ng} \mathrm{L}^{-1}$ ) according to Krachler et al. (2004).

The UV absorption spectra of pore water were measured with a spectrophotometer (Secoman UVi-light XT5) from 190 to $700 \mathrm{~nm}$ in a $1 \mathrm{~cm}$ quartz cell. The specific UV absorbance (SUVA) at $254 \mathrm{~nm}\left(\mathrm{~L} \mathrm{mg}^{-1} \mathrm{~m}^{-1}\right)$ was calculated as follows: SUVA $=A_{254} /(b \cdot \mathrm{DOC}$ ) (Weishaar et al., 2003), where $A_{254}$ is the sample absorbance at $254 \mathrm{~nm}$ (non-dimensional), $b$ is the optical path length $(\mathrm{m})$ and DOC $\left(\mathrm{mg} \mathrm{L}^{-1}\right)$. The baseline was determined with ultra-pure water. Potential additional absorbance related to Fe content was examined following the procedure described by Poulin et al. (2014). The additional absorbance was small and repre- 


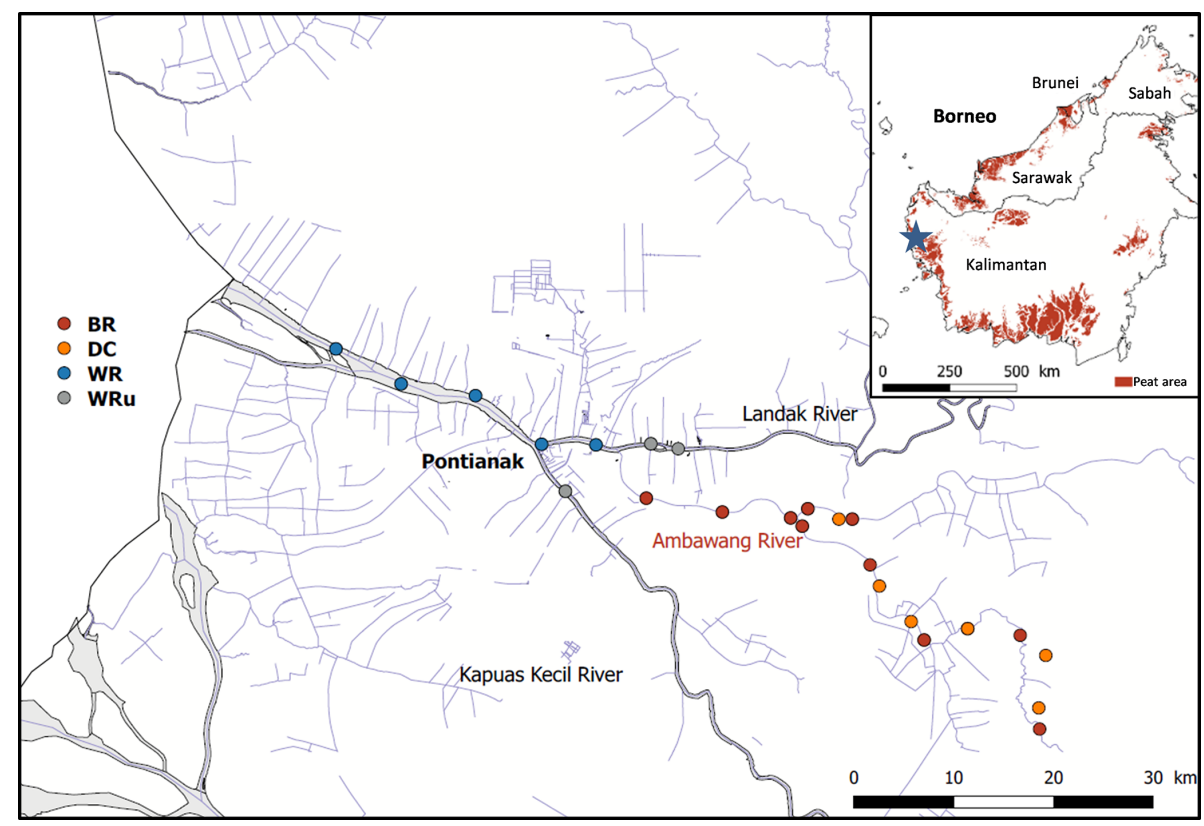

Figure 1. (a) Location of the study area on the island of Borneo. (b) Location of sampling sites and types of water: blackwater river (BR), drainage canal (DC), whitewater river (WR) and whitewater river upstream of the confluence with the blackwater river (WRu).

sented only $3.6 \pm 1.4 \%$ of the total absorbance across all samples and was therefore neglected.

Emission excitation matrices (EEMs) were acquired using a Hitachi F4500 fluorescence spectrometer, and instrumentspecific correction was applied. Emission spectra were acquired from 250 to $550 \mathrm{~nm}$ for excitation ranging from 250 to $550 \mathrm{~nm}$. The slits were set to $5 \mathrm{~nm}$ for both the excitation and emission monochromators. The scan speed was $2400 \mathrm{~nm} \mathrm{~min}^{-1}$ and the integration response was $0.1 \mathrm{~s}$. Fluorescence intensity was corrected from the excitation beam to ensure stability. The inner-filter effect water was taken into account using a dilution approach as developed by Luciani et al. (2009). The fluorescence index was calculated as defined by McKnight et al. (2001) and adapted by Jaffé et al. (2008): by the ratio of the fluorescence intensity at $470 \mathrm{~nm}$ to the fluorescence intensity at $520 \mathrm{~nm}$ for a $370 \mathrm{~nm}$ excitation. The shape of the excitation spectra was checked following the recommendation of Cory et al. (2010). The PARAFAC analysis (parallel factor analysis; Bro, 1997) was performed on all samples using the PROGMEEF program in MATLAB (Luciani et al., 2008).

The isotopic composition $\left(\delta^{13} \mathrm{C}\right)$ of DOC was determined at the UC Davis Stable Isotope Facility, following the described procedure (http://stableisotopefacility.ucdavis.edu/ doc.html, last access: 30 June 2019). Briefly, a TOC analyzer (OI Analytical, College Station, TX) is interfaced to a PDZ Europa 20-20 isotope ratio mass spectrometer (Sercon Ltd., Cheshire, UK) utilizing a GD100 Gas Trap Interface (Graden Instruments).

\subsection{Statistical analysis}

Statistical analysis was performed using R (R Core Team, 2019) and the $R$ studio software (Version 1.2.1335), using ggplot (Wickham, 2016), dplyr (Wickham et al., 2019) and dunn.test (Dinno, 2017) packages. Significant differences $(p<0.05)$ between groups were evaluated using KruskalWallis and Dunn's post hoc multiple test.

\section{Results}

\subsection{Trends in water chemistry from the source of the blackwater river to the ocean}

The observed water chemistry of the Ambawang River and drainage canals is typical of blackwater rivers draining peatlands (Table 1; Fig. 2) and does not show significant differences between the two sampling seasons. It is acidic, with a $\mathrm{pH}$ of $3.2 \pm 0.6$ and $3.5 \pm 0.3$ in the drainage canals and the blackwater river, respectively, has a low conductivity (DC: $89.8 \pm 21.4 \mu \mathrm{S} \mathrm{cm}^{-1}$; BR: $85.2 \pm 21.6 \mu \mathrm{S} \mathrm{cm}^{-1}$ ), is hypoxic (DC: $2.3 \pm 0.3$; BR: $1.9 \pm 0.7 \mathrm{mg} \mathrm{L}^{-1}$ ), and has low nutrient concentrations (dissolved inorganic nitrogen $<0.3 \mathrm{mg} \mathrm{L}^{-1}$ and $\mathrm{P}_{-} \mathrm{PO}_{4}<0.015 \mathrm{mg} \mathrm{L}^{-1}$ ) but high DOC concentrations (DC: $35.2 \pm 5.9$; BR: $35.8 \pm 3.5 \mathrm{mg} \mathrm{L}^{-1}$ ). The $\mathrm{Cl}^{-}$concentrations are low and homogeneous (DC: $2.6 \pm 0.7$; BR: $\left.2.4 \pm 0.6 \mathrm{mg} \mathrm{L}^{-1}\right)$. After the confluence with the whitewater river, the chemistry of the river radically changes. An abrupt increase in $\mathrm{pH}$ is observed (WR: $5.3 \pm 0.7$ ). The dissolved oxygen concentration increases to $3.7 \pm 1.0 \mathrm{mg} \mathrm{L}^{-1}$, while 

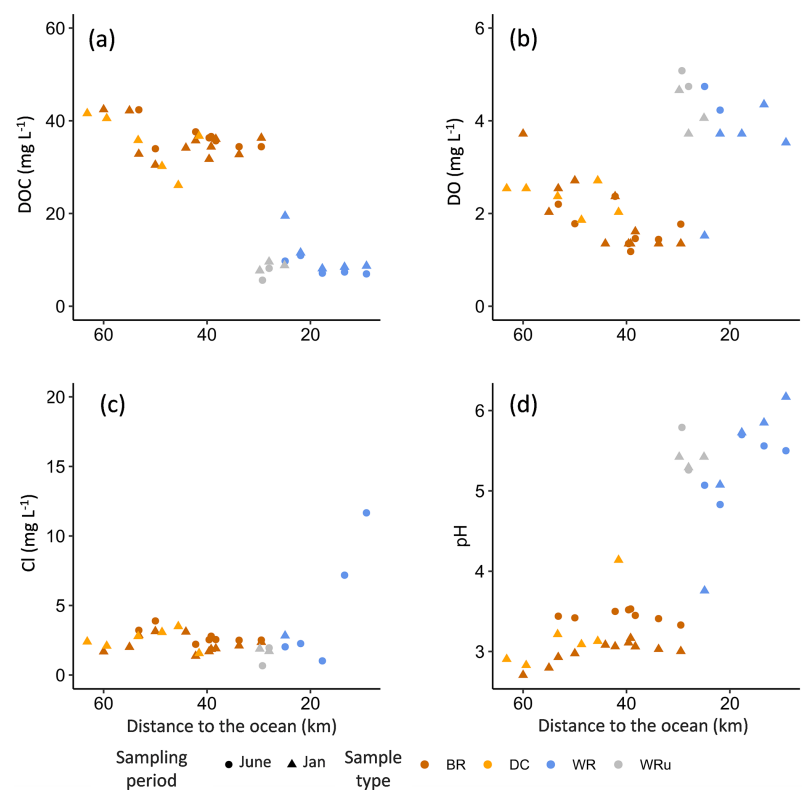

Figure 2. Evolution of (a) dissolved organic carbon (DOC) concentration, (b) dissolved oxygen (DO) concentration, (c) chloride concentration and (d) $\mathrm{pH}$ along the continuum from the blackwater river to the ocean.

DOC concentrations drop sharply to $9.2 \pm 3.2 \mathrm{mg} \mathrm{L}^{-1}$. We also observe a slight increase in $\mathrm{NO}_{3}^{-}$and decrease in $\mathrm{PO}_{4}^{2-}$. Across all samples, the DOC concentrations show a significant negative correlation with DO concentrations $\left(r^{2}=0.63\right.$, $\left.n=40, p<4 \times 10^{9}\right)$. In contrast, no increase in $\mathrm{Cl}^{-}$concentration is observed until close to the ocean (three samples corresponding to ocean water intrusion were excluded from Fig. 2).

\subsection{DOM optical characteristics and stable isotopic signature}

No systematic differences are observed for the DOM characteristics between the two sampling campaigns. The $\delta^{13} \mathrm{C}$ signature of DOC (Fig. 3a) is very negative, reaching $-30.3 \pm$ $0.4 \%$ in the drainage canals. It gradually and continually increases along the continuum from upstream in the blackwater river to the ocean (Fig. 3a). As a result, the $\delta^{13} \mathrm{C}$ of DOC in the drainage canals and the blackwater river is significantly more depleted than the whitewater river. The $\delta^{13} \mathrm{C}$ signature of DOC is significantly negatively correlated with DOC concentration $\left(r^{2}=0.68, p<10^{-4}, n=40\right)$, with the highest DOC values being associated with the lowest $\delta^{13} \mathrm{C}$-DOC values.

The SUVA index (Fig. 3b) has high values in the blackwater river $(5.3 \pm 1.2)$, with the highest values measured upstream. A wide range of values is measured in the drainage canals $(4.3 \pm 1.4)$. The SUVA values of the blackwater river are significantly higher than those measured in the Kapuas Kecil $(4.5 \pm 0.3)$ and its tributaries $(4.2 \pm 0.2)$. The fluores-

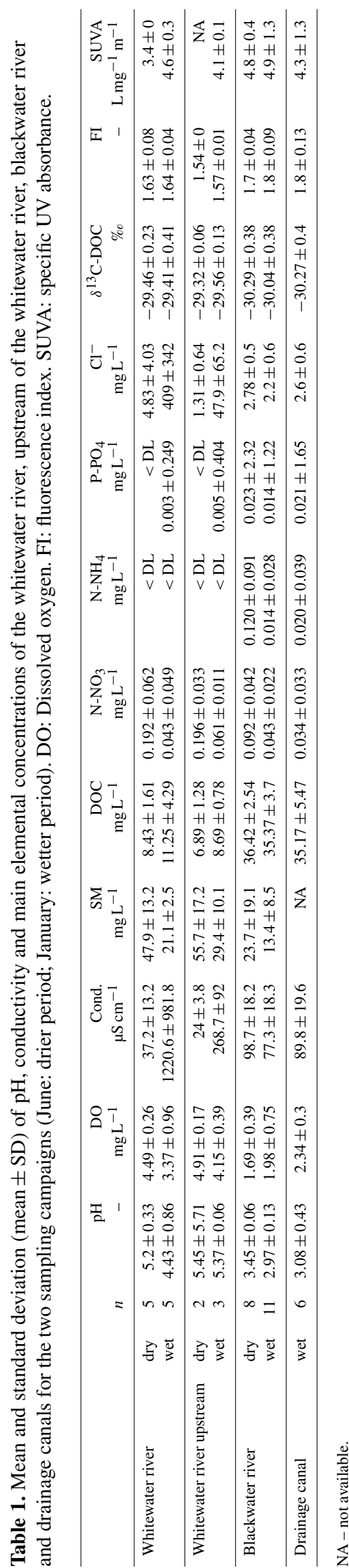

Biogeosciences, 17, 1897-1909, 2020 

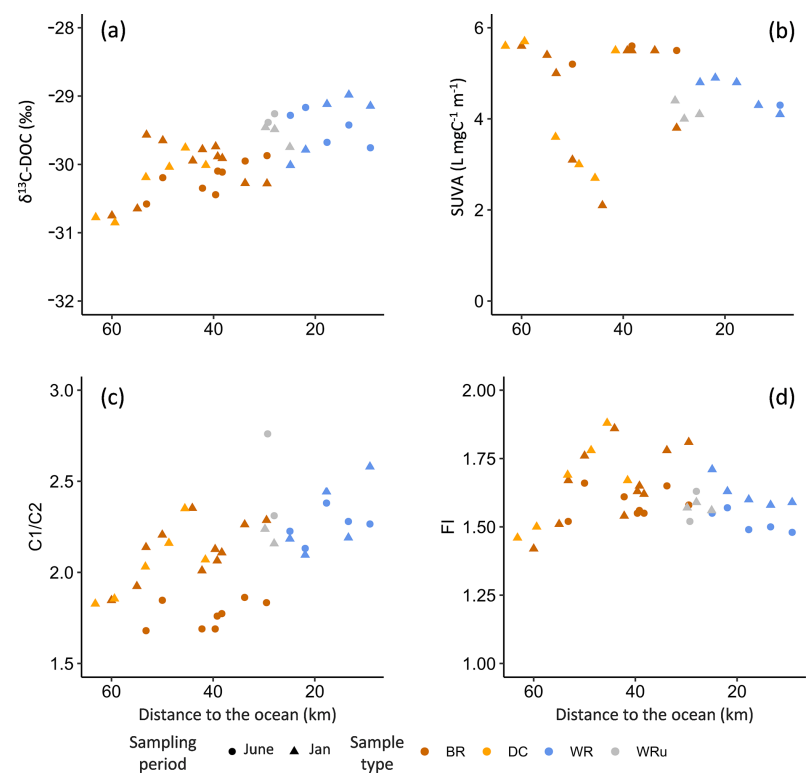

Figure 3. Evolution of DOM along the blackwater river to the ocean continuum. (a) $\delta^{13}$ C-DOC. (b) SUVA - specific UV absorbance index. (c) $\mathrm{C} 1 / \mathrm{C} 2$. (d) $\mathrm{FI}$ - fluorescence index.

cence index has relatively high values for tropical peatlands, where most of the DOM is of terrestrial origin (Gandois et al., 2014; Zhou et al., 2019). The FI values vary widely in the drainage canals $(1.60 \pm 0.17)$ and blackwater river $(1.55 \pm 0.06)$ but are more uniform in the whitewater river, both upstream $(1.55 \pm 0.03)$ and downstream $(1.55 \pm 0.05)$ of the confluence with the blackwater river. Despite the high FI values, these two optical indices show coherent spatial patterns within the blackwater river and drainage canals (Fig. 3b and d). For example, lower SUVA values are associated with higher FI values in three drainage canals and in the blackwater river close to their connection, sampled during the second sampling campaign. Across all samples, a significant correlation is observed between FI and SUVA values $\left(r^{2}=0.37\right.$, $p<10^{-4}, n=41$ ).

The EEMs of all water samples have two main peaks (Fig. S2). The primary peak $\left(\lambda_{\mathrm{ex}}=250 \mathrm{~nm}, \lambda_{\mathrm{em}}=460 \mathrm{~nm}\right)$ is coupled with a less intense peak $\left(\lambda_{\mathrm{ex}}=350 \mathrm{~nm}, \lambda_{\mathrm{em}}=\right.$ $460 \mathrm{~nm})$. The peaks are typical of high molecular weight and aromatic molecules, which have been observed in wetlands (Fellman et al., 2009). The PARAFAC analysis reveals two fluorophores: $\mathrm{C} 1\left(\lambda_{\mathrm{ex}}=255 \mathrm{~nm}, \lambda_{\mathrm{em}}=450 \mathrm{~nm}\right)$ and $\mathrm{C} 2$ $\left(\lambda_{\text {ex }}=285 \mathrm{~nm}, \lambda_{\text {em }}=485 \mathrm{~nm}\right.$; Fig. S3) The first component constitutes $60 \%-73 \%$ of the total fluorescence of samples. The relative contribution of these two fluorophores evolves along the sampled continuum, with the lowest values measured upstream in the blackwater river (Fig. 3c). The spatial evolutions of the $\mathrm{C} 1 / \mathrm{C} 2$ ratios and the $\delta^{13} \mathrm{C}$-DOC values show consistent trends. A significant $\left(r^{2}=0.43, p<0.001\right.$, $n=41$ ) relationship is observed across all the samples between these two indicators. A stronger relationship $\left(r^{2}=\right.$
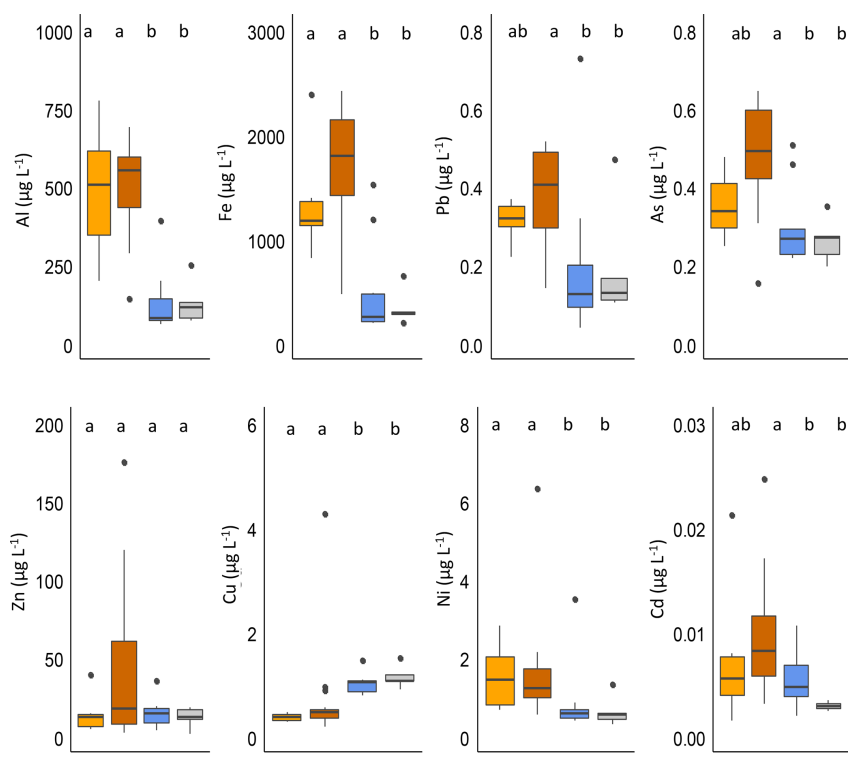

由R 甶DC 户WR 户WRu

Figure 4. Ranges of selected TM concentrations for different sampled water types. Letters represent significantly different groups (Kruskal-Wallis and Dunn's post hoc multiple test; $p<0.05$ ). The black line is the median. The lower and upper levels of the box represent the $25 \%$ and $75 \%$ quartile, respectively. The lower whisker is smallest observation greater than or equal to lower hinge $-1.5 \cdot \mathrm{IQR}$ (interquartile range). The upper whisker is the largest observation less than or equal to upper hinge $+1.5 \cdot \mathrm{IQR}$.

$0.85, p<0.001, n=5$ ) is observed when the drainage canal samples alone are considered.

\subsection{Trace element concentrations and physical fractionation}

Blackwater rivers originating from drained peatlands have a unique composition of inorganic elements. The concentrations of trace metals $(\mathrm{Pb}, \mathrm{Ni}, \mathrm{Zn}, \mathrm{Cd})$ as well as $\mathrm{Al}$ and $\mathrm{Fe}$ are significantly higher in the blackwater river and drainage canals than in the whitewater river (Table 2; Fig. 4). For Al, $\mathrm{Fe}$ and As, high concentrations are measured in the blackwater river during the first sampling campaign (drier conditions). In contrast to other TMs, higher $\mathrm{Cu}$ concentrations are measured in the whitewater river. A principal component analysis (PCA; Fig. 5) of TM concentration and DOM properties reveals specific associations between DOC, Fe and As and to a lesser extent $\mathrm{Zn}$ and $\mathrm{Cd}$, while another group is formed by $\mathrm{Al}, \mathrm{Pb}$ and $\mathrm{Ni}$. Copper shows no association with DOM but does show increased concentrations with higher FI. The first axis of PCA (load of DOC, Fe, As) strongly discriminates the blackwater river and drainage canal samples from the whitewater river.

The distributions of DOC and TMs are presented in Table 3. Dissolved organic carbon is mostly (> 98\%) dissolved 

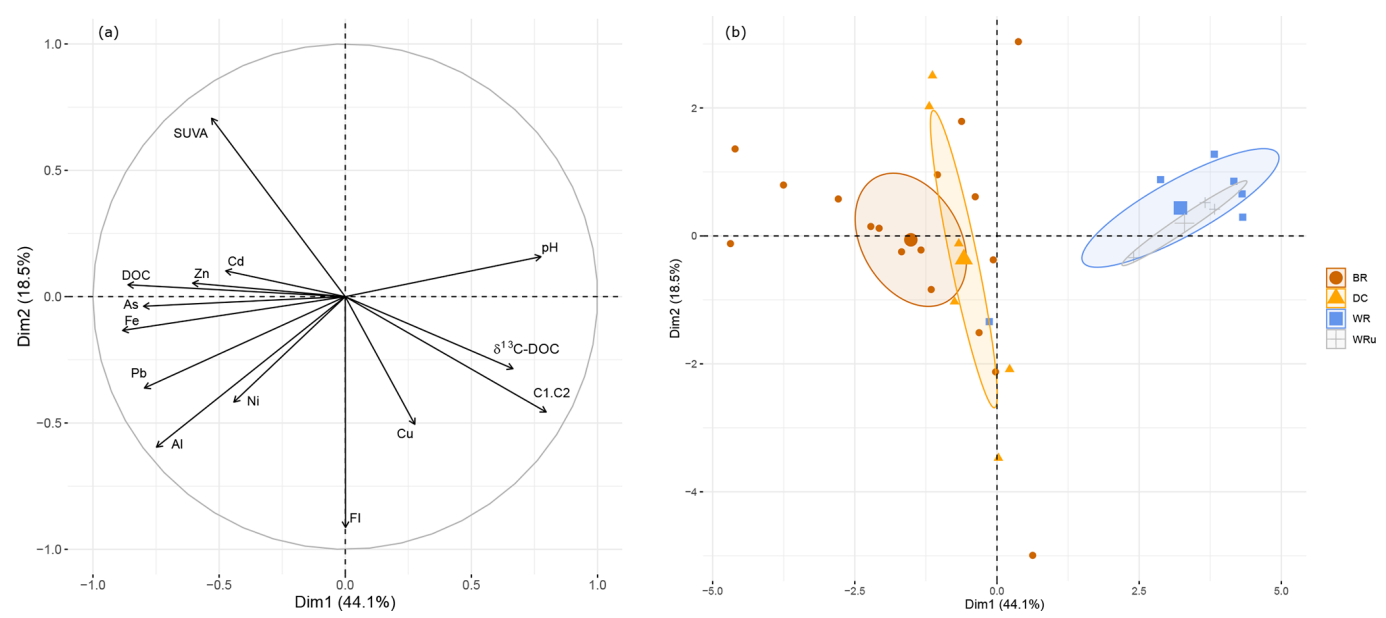

Figure 5. The first two factors of the PCA (62.6\% of variance) by variables (a) and by observations (b) for the different sampled water types.

or in the form of fine colloids $(<0.22 \mu \mathrm{m})$ along the entirety of the studied continuum. Iron and As are mostly present in dissolved form or as fine colloids in the blackwater river and drainage canals ( $>96 \%$ ). However, after transfer to the whitewater river, half of $\mathrm{Fe}$ and a third of $\mathrm{As}$ are present in the coarse colloidal form. Zinc and Cd do not show similar patterns. Aluminum is mostly present in the coarse colloidal phase $(>60 \%)$ in the blackwater river and drainage canals, and this proportion further increases in the whitewater river $(>80 \%)$. Lead is mostly present in the dissolved and fine colloid phase $(>75 \%)$ in the drainage canals and blackwater river and shifts to coarse colloidal $(>60 \%)$ forms after the confluence with the whitewater river. Nickel and $\mathrm{Cu}$ are mostly present in the dissolved and fine colloidal phase in the DC and BR but almost entirely in the coarse colloidal fraction in the whitewater river.

\subsection{Pb isotopic composition}

We observe distinct differences between the lead isotope ratios in the whitewater river and those in the blackwater river and drainage canals. A decrease in the ${ }^{206} \mathrm{~Pb} /{ }^{207} \mathrm{~Pb}$ isotopic ratio is observed with increasing $\mathrm{Pb}$ concentrations in the blackwater river but not the whitewater river (Fig. 6a). Furthermore, the biplot of the ${ }^{206} \mathrm{~Pb} /{ }^{207} \mathrm{~Pb}$ and the ${ }^{208} \mathrm{~Pb} /{ }^{206} \mathrm{~Pb}$ signatures illustrates significant differences between the white water and blackwater river and drainage canal groups (Fig. 6b).

\section{Discussion}

\subsection{In-stream processing of DOM in blackwater rivers}

We observe in-stream processing of DOM, but the total DOM exported from tropical peatlands exceeds the processing capacity of the rivers which drain them and a large proportion of DOM is transported to the ocean. We find persistently
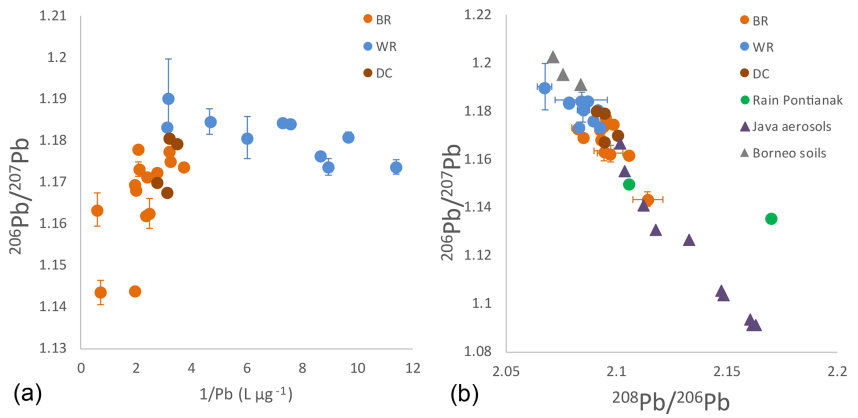

Figure 6. (a) Dependence of ${ }^{206 / 207} \mathrm{~Pb}$ ratio on $\mathrm{Pb}$ concentrations for the different water samples. (b) Relationship between ${ }^{206} \mathrm{~Pb} /{ }^{207} \mathrm{~Pb}$ ratio and ${ }^{208} \mathrm{~Pb} /{ }^{206} \mathrm{~Pb}$ ratio. The error bars represent the standard deviation.

high DOC concentrations in both drainage canals and blackwater rivers draining degraded peatlands, consistent with the range of previously reported values in Borneo (Moore et al., 2011; Cook et al., 2018) and in the upper range of blackwater rivers in Sumatra (Baum et al., 2007; Rixen et al., 2008). We also find indicators of in-stream processing of DOM. The transformation of DOM we observe along the continuum is likely primarily due to photo-oxidation, with a smaller contribution from microbial processing. We observe an increase in the $\delta^{13} \mathrm{C}$-DOC values along the studied continuum (Fig. 3a). This shift toward higher $\delta^{13} \mathrm{C}$-DOC is correlated with an increase in the $\mathrm{C} 1 / \mathrm{C} 2$ ratio of PARAFAC fluorophores (Fig. 3c). The two fluorophores are typical of terrestrial input of DOM (Yamashita et al., 2008) and similar to observed fluorophores in other blackwater rivers in Borneo (Harun et al., 2015; Zhou et al., 2019). An increase in this $\mathrm{C} 1 / \mathrm{C} 2$ ratio reflects a shift toward lower wavelengths and therefore toward lower aromaticity and lower molecular weight (Austnes et al., 2010; Zhou et al., 2019). Moreover, a decreasing trend in SUVA values is observed along 


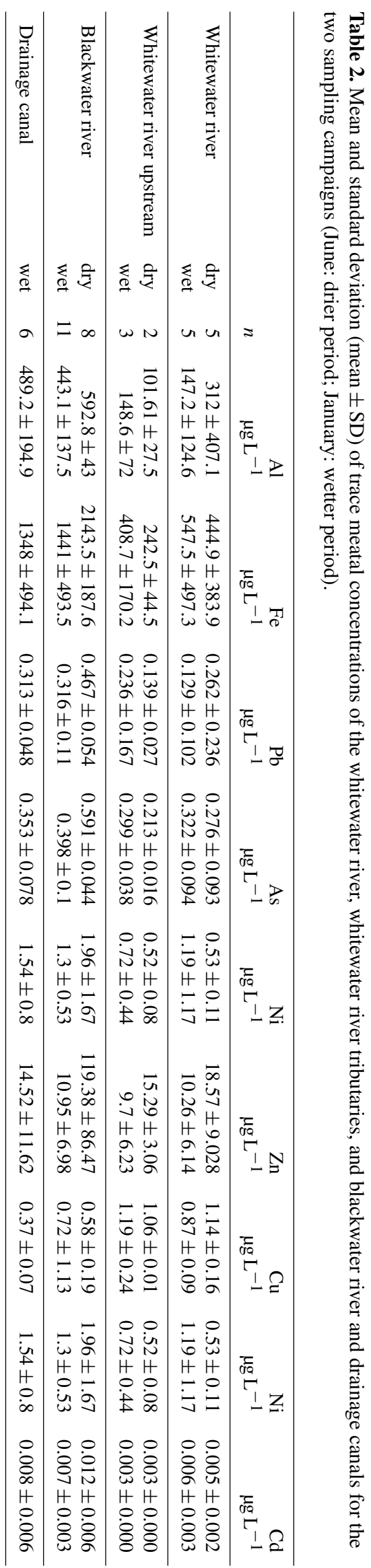

the continuum (Fig. 3b). These observations indicate that at our site, aromatic features are preferentially processed instream, consistent with a dominant effect of photo-oxidation (Amon and Benner, 1996; Spencer et al., 2009; Sharpless et al., 2014). This has also been observed in the Congo River, where photo-oxidation led to an increase in $\delta^{13} \mathrm{C}$-DOC and a decrease in aromatic features (Spencer et al., 2009).

However, photo-oxidation is not the only process responsible for the processing of DOM. The low oxygen levels in the blackwater river and drainage canals and the significant relationship between DOC and DO concentrations suggest that nearly all oxygen entering the well-mixed water is quickly consumed by DOM oxidation (Fig. 2a and b). Furthermore, the sharply decreasing oxygen profiles measured in the blackwater river suggest that the transformation of DOM is restricted to the shallow surface layers of these waters (Fig. S3). Additionally, localized increases in fluorescence index, coupled with decreases in SUVA (reflecting a higher proportion of microbial derived DOM; Fig. 3d), suggest that microbial processing occurs in some locations in drainage canals. Both photo-oxidation and microbial processing have been quantified in laboratory experiments for DOM originating from tropical peatlands. Martin et al. (2018) found that up to $25 \%$ of riverine DOC from a blackwater river in Sarawak, Malaysia, was lost within $5 \mathrm{~d}$ of exposure to natural sunlight. Microbial long-term incubation studies by Rixen et al. (2008) showed that $27 \%$ of DOC was degraded after 2 weeks. In blackwater rivers, it is likely that in-stream microbial processing of DOM is limited by the low oxygen concentrations, low $\mathrm{pH}$ and low nutrient levels (especially inorganic nitrogen; Wickland et al., 2012) rather than intrinsic refractory characteristics. Although the precise extent of in-stream processing cannot be quantified here, our results are consistent with in-stream transformation of DOM by photo-oxidation as well as some contribution of microbial degradation in the shallow surface layers. In the future, quantitative assessment of outgassing in tropical peatland drainage canals would improve the evaluation of carbon release following peatland drainage. Overall, more work is needed to understand the extent of upstream processing of peatland DOM.

\subsection{Role of $\mathrm{DOM}, \mathrm{Al}$ and $\mathrm{Fe}$ in trace metal dynamics in peat-draining waters}

This study provides the first record of trace metals in blackwater rivers originating from degraded tropical peatlands. We observe strong enrichment of $\mathrm{Al}$ and $\mathrm{Fe}$ as well as $\mathrm{Pb}, \mathrm{As}$, $\mathrm{Ni}$ and $\mathrm{Cd}$ in peat-draining waters. The measured concentrations are comparable to those measured by Kurasaki et al. (2000) in Borneo rivers for $\mathrm{Pb}, \mathrm{Zn}, \mathrm{Cu}$ and $\mathrm{Cd}$ but significantly higher (5 to 10 times) for Fe. The concentration levels, however, remain low compared to highly impacted regions of Indonesia (Arifin et al., 2012). The elevated concentrations of $\mathrm{Al}$ and $\mathrm{Fe}$ in water draining tropical peatlands is consis- 
Table 3. Proportion of DOC and selected trace metals in the form of dissolved and fine colloids $(<0.22 \mu \mathrm{m})$ and coarse colloids $(0.2-2.7 \mu \mathrm{m})$.

\begin{tabular}{lrr|rr|rr}
\hline & \multicolumn{2}{c|}{ Drainage canals } & \multicolumn{2}{c|}{ Blackwater river } & \multicolumn{2}{c}{ Whitewater river } \\
\cline { 2 - 7 } & $<0.2 \mu \mathrm{m}$ & $0.2-2.7 \mu \mathrm{m}$ & $<0.2 \mu \mathrm{m}$ & $0.2-2.7 \mu \mathrm{m}$ & $<0.2 \mu \mathrm{m}$ & $0.2-2.7 \mu \mathrm{m}$ \\
\hline $\mathrm{DOC}$ & 97 & 3 & 98 & 2 & 100 & 0 \\
$\mathrm{Al}$ & 39 & 61 & 36 & 64 & 18 & 82 \\
$\mathrm{Fe}$ & 100 & 0 & 99 & 1 & 45 & 55 \\
$\mathrm{~Pb}$ & 75 & 25 & 78 & 22 & 34 & 66 \\
$\mathrm{As}$ & 98 & 2 & 96 & 4 & 67 & 33 \\
$\mathrm{Ni}$ & 72 & 28 & 50 & 50 & 1 & 99 \\
$\mathrm{Cu}$ & 68 & 32 & 48 & 52 & 1 & 99 \\
$\mathrm{Zn}$ & 13 & 87 & 12 & 88 & 26 & 74 \\
$\mathrm{Cd}$ & 66 & 34 & 100 & 0 & 83 & 17 \\
\hline
\end{tabular}

tent with existing observations of elevated $\mathrm{Fe}$ concentrations from blackwater rivers in the tropics (Zhang et al., 2019) and northern peatlands. This enrichment is likely due to the weathering of mineral material under the peat during peat accumulation processes (Tipping et al., 2002; Pokrovsky et al., 2005). As a consequence, in water draining peatlands, strong organo-mineral associations between DOM and Fe (Krachler et al., 2010, 2012; Broder and Biester, 2015) and DOM and Al (Helmer et al., 1990) have been observed. These colloidal associations between $\mathrm{DOM}$ and $\mathrm{Al}$ and $\mathrm{Fe}$ in the form of hydroxides strongly control TM transfer and speciation in peat-draining waters (Tipping et al., 2002). In the present study, specific associations of trace metals with $\mathrm{Al}$ and $\mathrm{Fe}$ are observed, including strong links between $\mathrm{Al}$ and $\mathrm{Pb}$ and Ni. However, the lack of a direct relationship between $\mathrm{Pb}$ and DOM contrasts with reported observations in the literature (Graham et al., 2006; Pokrovsky et al., 2016; Jeremiason et al., 2018). Despite this, we do observe strong links between $\mathrm{Fe}, \mathrm{As}, \mathrm{Zn}, \mathrm{Cd}$ and DOM, which have been previously reported in water draining peatlands (Neubauer et al., 2013; Broder and Biester, 2015; Pokrovsky et al., 2016). The coupled dynamics of $\mathrm{Fe}$ and As might be related to similar mobilization processes within the peat column, with the sorption of As to Fe(III)-(oxyhydr)oxides (ThomasArrigo et al., 2014) in anoxic peat water. Widespread drainage of tropical peatlands and the corresponding release of anoxic water to surface water networks could induce a coupled increase in DOM and Fe concentrations, similar to that which has occurred in Sweden (Kritzberg and Ekström, 2012).

\subsection{Peatlands as secondary sources of atmospheric pollutants}

The isotopic composition of $\mathrm{Pb}$ in peat-draining water strongly suggests that it is of anthropogenic origin. The isotopic signatures measured in river samples are a combination of the signature of undisturbed soils of Borneo (Valentine et al., 2008) and a mix of both present and past anthropogenic inputs. Older anthropogenic inputs are reflected by the signature of atmospheric deposition from Java aerosols (Boll- höfer and Rosman, 2000), while the signature of recent regional anthropogenic inputs was characterized by rain samples collected in Pontianak as part of this study (Fig. 6b). In the blackwater river and drainage canals, the isotopic ratio is close to that of aerosols and recently sampled rainwater and is dominated by anthropogenic inputs, whereas the isotopic ratio in the whitewater river is closer to the natural signal (Fig. 6). This isotopic difference is consistent with the difference between the watersheds drained by these two rivers: tropical peatlands are ombrotrophic systems, and the trace metal content in peat soil is derived from the atmosphere (Weiss et al., 2002), whereas the Kapuas Kecil is recharged from a larger watershed and reflects contribution of mineral soils. Tropical peatlands can serve as secondary sources of atmospheric pollutants to the environment. With peatland drainage, blackwater rivers release the accumulated atmospheric deposition over hundreds of years on much shorter timescales. For example, the isotopic signature observed in the blackwater river reflects anthropogenic sources deposited at different times, including older deposition such as the lead measured in the Java aerosols (Bollhöfer and Rosman, 2000), and more recent deposition following the widespread introduction of unleaded fuel (characterized by samples collected from rainwater during the January 2014 sampling period in this study). This release of lead by degraded tropical peatlands has the potential to impact records from environmental archives, for example the corals of the Singapore Strait (Chen et al., 2015). Although this is the first measurement of the aquatic release of trace metals from tropical peatlands, the role of tropical peatlands as a secondary source of contaminants has also been highlighted by the trace metal content analysis of dust emitted to the atmosphere by peat fires (Betha et al., 2013).

\subsection{From degraded tropical peatlands to the ocean}

Sharp changes in physico-chemical conditions are observed after the mixing of the black and the whitewater river, including sharp increases in DO concentrations and $\mathrm{pH}$ values. This strongly controls the transport of DOM and TMs 
drained from degraded tropical peatlands. After the confluence with the whitewater river, DOC concentrations decrease abruptly. This decrease primarily results from the dilution of the blackwater river signal. However, the sudden elevation of $\mathrm{pH}$ and DO after the confluence might create favorable conditions for microbial processing of DOC, making the mixing zone a likely hotspot of GHG emissions (Palmer et al., 2016). This would also be consistent with the decrease in the SUVA index observed after the confluence. Despite processing of DOM along the continuum, a significant proportion of DOM originating from degraded peatlands actually reaches the ocean. We observe high DOC concentrations at all sampling locations, with concentrations remaining high even close to the ocean (Fig. 2a). Additionally, the results of our physical fractionation show that even close to the estuary, DOC remains in the dissolved and fine colloid form $(<0.22 \mu \mathrm{m})$ and that flocculation processes might be limited. The large areas of coastal peatlands in the region might explain the relatively high fluvial organic carbon export to the South China Sea (Huang et al., 2017). The decrease in trace metal concentrations after the confluence might be influenced by shifts in physical fractionation and an increased proportion of colloidal form. This is especially true for $\mathrm{Al}$ and $\mathrm{Pb}$. Some flocculation at the estuary might limit their transfer to the ocean. For Fe and As, a higher proportion remains in the form of fine colloids after mixing with the whiter river and is still associated with DOC. Similar conservative behavior of low-molecular-weight organic molecules associated with $\mathrm{Fe}$ was observed at the outlet of northern peatlands (Krachler et al., 2012) and in Arctic rivers (Pokrovsky et al., 2014). This highlights the finding that dissolved organic molecules derived from tropical peatlands can also act as carriers of trace metals to the ocean.

\section{Conclusions}

This study characterizes the composition and concentration of DOM and TMs in the canals and rivers draining the degraded tropical peatlands of Indonesian Borneo. It highlights in-stream processing of DOM in drainage canals and rivers draining degraded peatlands. Both stable isotopic and optical properties of DOM are consistent with photo-oxidation along the continuum from the blackwater river to the ocean. In the blackwater river and drainage canals, rates of microbial processing are likely limited to shallow depths. Along the continuum, DOM is found at relatively high concentrations in the dissolved and fine colloidal phases, suggesting that a substantial fraction of DOM derived from degraded peatlands reaches the ocean. Additionally, we provide the first assessment of trace metal concentrations in rivers draining degraded tropical peatlands. Rivers draining these peatlands are enriched in some trace metals $(\mathrm{Pb}, \mathrm{Ni}, \mathrm{Zn}, \mathrm{Cd})$ as well as $\mathrm{Al}$ and $\mathrm{Fe}$. Using the isotopic signature of $\mathrm{Pb}$, we show that degraded tropical peatlands are secondary sources of atmo- spherically deposited contaminants to surface waters. Trace metal dynamics after transfer to the whitewater river show clear trends: while $\mathrm{Pb}$ and $\mathrm{Ni}$ are associated with $\mathrm{Al}, \mathrm{As}, \mathrm{Zn}$ and $\mathrm{Cd}$ are associated with $\mathrm{Fe}$ and DOM. Lead and $\mathrm{Al}$ are present in coarse colloidal form and may be transferred to sediments after flocculation. In contrast, DOM, Fe and As are found predominantly in fine colloidal form even after the confluence with the whitewater river and as a result may be transferred to the ocean. The role of degraded tropical peatlands as a source of DOM, as well as Fe and As to the ocean, requires further investigation.

Data availability. The data are available at https://doi.pangaea.de/ 10.1594/PANGAEA.909094 (Gandois et al., 2019).

Supplement. The supplement related to this article is available online at: https://doi.org/10.5194/bg-17-1897-2020-supplement.

Author contributions. LG, AMH, GA and CFH designed the study. LG, AMH, MN and GH conducted field campaigns. SM and LG conducted fluorescence analysis. GLR and AC conducted lead isotope analysis. LG and AMH wrote the paper, with input from all co-authors.

Competing interests. The authors declare that they have no conflict of interest.

Special issue statement. This article is part of the special issue "Biogeochemical processes in highly dynamic peat-draining rivers and estuaries in Borneo". It is not associated with a conference.

Acknowledgements. This research was supported by the National Research Foundation Singapore through the Singapore-MIT Alliance for Research and Technology's Center for Environmental Sensing and Modeling interdisciplinary research program and grant no. NRF2016-ITCOO1-021, by the US National Science Foundation under grant no. 1923478 to Charles F. Harvey, and by the PEER project "Assessing Degradation of Tropical Peat Domes and Dissolved Organic Carbon (DOC) Export from the Belait, Mempawah and Lower Kapuas Kecil Rivers in Borneo" led by Gusti Anshari. We thank Frederic Julien, Virginie Payre-Suc and Didier Lambrigot for DOC and major element analysis (PAPC platform, EcoLab laboratory) and Frédéric Candaudap for lead isotope analysis (ICP-MS platform, GET laboratory). We also thank Patrick Martin and one anonymous reviewer for their constructive comments that improved the paper.

Financial support. This research has been supported by the US-Aid (PEER project "Assessing Degradation of Tropical Peat Domes and Dissolved Organic Carbon (DOC) Export from the 
Belait, Mempawah and Lower Kapuas Kecil Rivers in Borneo"), the Singapore-MIT Alliance for Research and Technology (Center for Environmental Sensing and Modeling Interdisciplinary Research Program), and the US National Science Foundation (grant nos. 1114155 and 1114161).

The article processing charges for this open-access publication were covered by the Max Planck Society.

Review statement. This paper was edited by Phillip Ford and reviewed by Patrick Martin and one anonymous referee.

\section{References}

Alkhatib, M., Jennerjahn, T. C., and Samiaji, J.: Biogeochemistry of the Dumai River estuary, Sumatra, Indonesia, a tropical black-water river, Limnol. Oceanogr., 52, 2410-2417, https://doi.org/10.4319/1o.2007.52.6.2410, 2007.

Amon, R. M. W. and Benner, R.: Photochemical and microbial consumption of dissolved organic carbon and dissolved oxygen in the Amazon River system, Geochim. Cosmochim. Ac., 60, 17831792, https://doi.org/10.1016/0016-7037(96)00055-5, 1996.

Arifin, Z., Puspitasari, R., and Miyazaki, N.: Heavy metal contamination in Indonesian coastal marine ecosystems: A historical perspective, Coast. Mar. Sci., 35, 227-233, 2012.

Austnes, K., Evans, C. D., Eliot-Laize, C., Naden, P. S., and Old, G. H.: Effects of storm events on mobilisation and in-stream processing of dissolved organic matter (DOM) in a Welsh peatland catchment, Biogeochemistry, 99, 157-173, https://doi.org/10.1007/s10533-009-9399-4, 2010.

Barber, A., Sirois, M., Chaillou, G., and Gélinas, Y.: Stable isotope analysis of dissolved organic carbon in Canada's eastern coastal waters, Limnol. Oceanogr., 62, S71-S84, https://doi.org/10.1002/lno.10666, 2017.

Baum, A., Rixen, T., and Samiaji, J.: Relevance of peat draining rivers in central Sumatra for the riverine input of dissolved organic carbon into the ocean, Estuar. Coast. Shelf S., 73, 563-570, https://doi.org/10.1016/j.ecss.2007.02.012, 2007.

Betha, R., Pradani, M., Lestari, P., Joshi, U. M., Reid, J. S., and Balasubramanian, R.: Chemical speciation of trace metals emitted from Indonesian peat fires for health risk assessment, Atmos. Res., 122, 571-578, https://doi.org/10.1016/j.atmosres.2012.05.024, 2013.

Bollhöfer, A. and Rosman, K. J. R.: Isotopic source signatures for atmospheric lead: the Southern Hemisphere, Geochim. Cosmochim. Ac., 64, 3251-3262, https://doi.org/10.1016/S00167037(00)00436-1, 2000.

Bro, R.: PARAFAC. Tutorial and applications - ScienceDirect, Chemom. Intell. Lab. Syst., 38, 149-171, https://doi.org/10.1016/S0169-7439(97)00032-4, 1997.

Broder, T. and Biester, H.: Hydrologic controls on DOC, $\mathrm{As}$ and $\mathrm{Pb}$ export from a polluted peatland - the importance of heavy rain events, antecedent moisture conditions and hydrological connectivity, Biogeosciences, 12, 4651-4664, https://doi.org/10.5194/bg-12-4651-2015, 2015.

Broder, T. and Biester, H.: Linking major and trace element concentrations in a headwater stream to DOC release and hydrologic conditions in a bog and peaty riparian zone, Appl. Geochem., 87, 188-201, https://doi.org/10.1016/j.apgeochem.2017.11.003, 2017.

Carlson, K. M., Goodman, L. K., and May-Tobin, C. C.: Modeling relationships between water table depth and peat soil carbon loss in Southeast Asian plantations, Environ. Res. Lett., 10, 074006, https://doi.org/10.1088/1748-9326/10/7/074006, 2015.

Chen, M., Lee, J.-M., Nurhati, I. S., Switzer, A. D., and Boyle, E. A.: Isotopic record of lead in Singapore Straits during the last 50 years: Spatial and temporal variations, Mar. Chem., 168, 49-59, https://doi.org/10.1016/j.marchem.2014.10.007, 2015.

Cobb, A. R., Hoyt, A. M., Gandois, L., Eri, J., Dommain, R., Salim, K. A., Kai, F. M., Su'ut, N. S. H., and Harvey, C. F.: How temporal patterns in rainfall determine the geomorphology and carbon fluxes of tropical peatlands, P. Natl. Acad. Sci. USA, 114, E5187-E5196, https://doi.org/10.1073/pnas.1701090114, 2017.

Cook, S., Whelan, M. J., Evans, C. D., Gauci, V., Peacock, M., Garnett, M. H., Kho, L. K., Teh, Y. A., and Page, S. E.: Fluvial organic carbon fluxes from oil palm plantations on tropical peatland, Biogeosciences, 15, 7435-7450, https://doi.org/10.5194/bg-15-7435-2018, 2018.

Cory, R. M., Miller, M. P., McKnight, D. M., Guerard, J. J., and Miller, P. L.: Effect of instrument-specific response on the analysis of fulvic acid fluorescence spectra, Limnol. Oceanogr.-Meth., 8, 67-78, https://doi.org/10.4319/lom.2010.8.67, 2010.

Couwenberg, J., Dommain, R., and Joosten, H.: Greenhouse gas fluxes from tropical peatlands in south-east Asia, Glob. Change Biol., 16, 1715-1732, https://doi.org/10.1111/j.13652486.2009.02016.x, 2010.

Dargie, G. C., Lewis, S. L., Lawson, I. T., Mitchard, E. T. A., Page, S. E., Bocko, Y. E., and Ifo, S. A.: Age, extent and carbon storage of the central Congo Basin peatland complex, Nature, 542, 8690, https://doi.org/10.1038/nature21048, 2017.

Dinno, A.: dunn.test: Dunn's Test of Multiple Comparisons Using Rank Sums, R package version 1.3.5, available at: https://CRAN. R-project.org/package=dunn.test (last access: 30 June 2019), 2017.

Fellman, J. B., Miller, M. P., Cory, R. M., D’Amore, D. V., and White, D.: Characterizing Dissolved Organic Matter Using PARAFAC Modeling of Fluorescence Spectroscopy: A Comparison of Two Models, Environ. Sci. Technol., 43, 6228-6234, https://doi.org/10.1021/es900143g, 2009.

Gandois, L., Cobb, A. R., Hei, I. C., Lim, L. B. L., Salim, K. A., and Harvey, C. F.: Impact of deforestation on solid and dissolved organic matter characteristics of tropical peat forests: implications for carbon release, Biogeochemistry, 114, 183-199, https://doi.org/10.1007/s10533-012-9799-8, 2013.

Gandois, L., Teisserenc, R., Cobb, A. R., Chieng, H. I., Lim, L. B. L., Kamariah, A. S., Hoyt, A., and Harvey, C. F.: Origin, composition, and transformation of dissolved organic matter in tropical peatlands, Geochim. Cosmochim. Ac., 137, 35-47, https://doi.org/10.1016/j.gca.2014.03.012, 2014.

Gandois, L., Hoyt, A. M., Mounier, S., Le Roux, G., Harvey, C. F., Claustres, A., Nuriman, M., and Anshari, G.: Dissolved Organic Matter and Trace Metal Composition in Rivers Draining Degraded Tropical Peatlands in West Kalimantan, Indonesia, PANGAEA, https://doi.org/10.1594/PANGAEA.909094, 2019.

Graham, M. C., Vinogradoff, S. I., Chipchase, A. J., Dunn, S. M., Bacon, J. R., and Farmer, J. G.: Using Size Fractionation and 
$\mathrm{Pb}$ Isotopes to Study $\mathrm{Pb}$ Transport in the Waters of an OrganicRich Upland Catchment, Environ. Sci. Technol., 40, 1250-1256, https://doi.org/10.1021/es0517670, 2006.

Hansen, A. M., Kraus, T. E. C., Pellerin, B. A., Fleck, J. A., Downing, B. D., and Bergamaschi, B. A.: Optical properties of dissolved organic matter (DOM): Effects of biological and photolytic degradation, Limnol. Oceanogr., 61, 1015-1032, https://doi.org/10.1002/lno.10270, 2016.

Harun, S., Baker, A., Bradley, C., Pinay, G., Boomer, I., and Liz Hamilton, R.: Characterisation of dissolved organic matter in the Lower Kinabatangan River, Sabah, Malaysia, Hydrol. Res., 46, 411-428, https://doi.org/10.2166/nh.2014.196, 2015.

Helmer, E. H., Urban, N. R., and Eisenreich, S. J.: Aluminum geochemistry in peatland waters, Biogeochemistry, 9, 247-276, https://doi.org/10.1007/BF00000601, 1990.

Hood, E., Williams, M. W., and McKnight, D. M.: Sources of dissolved organic matter (DOM) in a Rocky Mountain stream using chemical fractionation and stable isotopes, Biogeochemistry, 74, 231-255, https://doi.org/10.1007/s10533-004-4322-5, 2005

Hooijer, A., Page, S., Jauhiainen, J., Lee, W. A., Lu, X. X., Idris, A., and Anshari, G.: Subsidence and carbon loss in drained tropical peatlands, Biogeosciences, 9, 1053-1071, https://doi.org/10.5194/bg-9-1053-2012, 2012

Hoyt, A. M., Gandois, L., Eri, J., Kai, F. M., Harvey, C. F., and Cobb, A. R.: $\mathrm{CO}_{2}$ emissions from an undrained tropical peatland: Interacting influences of temperature, shading and water table depth, Glob. Change Biol., 25, 2885-2899, https://doi.org/10.1111/gcb.14702, 2019.

Huang, T. H., Chen, C. T. A., Tseng, H. C., Lou, J. Y., Wang, S. L., Yang, L., Kandasamy, S., Gao, X., Wang, J. T., Aldrian, E., Jacinto, G. S., Anshari, G. Z., Sompongchaiyakul, P., and Wang, B. J.: Riverine carbon fluxes to the South China Sea, J. Geophys. Res.-Biogeo., 122, 1239-1259, https://doi.org/10.1002/2016JG003701, 2017.

Jaffé, R., McKnight, D., Maie, N., Cory, R., McDowell, W. H., and Campbell, J. L.: Spatial and temporal variations in DOM composition in ecosystems: The importance of long-term monitoring of optical properties, J. Geophys. Res.-Biogeo., 113, G04032, https://doi.org/10.1029/2008JG000683, 2008.

Jauhiainen, J., Hooijer, A., and Page, S. E.: Carbon dioxide emissions from an Acacia plantation on peatland in Sumatra, Indonesia, Biogeosciences, 9, 617-630, https://doi.org/10.5194/bg-9617-2012, 2012.

Jeremiason, J. D., Baumann, E. I., Sebestyen, S. D., Agather, A. M., Seelen, E. A., Carlson-Stehlin, B. J., Funke, M. M., and Cotner, J. B.: Contemporary Mobilization of Legacy $\mathrm{Pb}$ Stores by DOM in a Boreal Peatland, Environ. Sci. Technol., 52, 33753383, https://doi.org/10.1021/acs.est.7b06577, 2018.

Krachler, M., Roux, G. L., Kober, B., and Shotyk, W.: Optimising accuracy and precision of lead isotope measurement $\left({ }^{206} \mathrm{~Pb}\right.$, ${ }^{207} \mathrm{~Pb},{ }^{208} \mathrm{~Pb}$ ) in acid digests of peat with ICP-SMS using individual mass discrimination correction, J. Anal. Atom. Spectrom., 19, 354-361, https://doi.org/10.1039/B314956K, 2004.

Krachler, R., Krachler, R. F., von der Kammer, F., Süphandag, A., Jirsa, F., Ayromlou, S., Hofmann, T., and Keppler, B. K.: Relevance of peat-draining rivers for the riverine input of dissolved iron into the ocean, Sci. Total Environ., 408, 2402-2408, https://doi.org/10.1016/j.scitotenv.2010.02.018, 2010.
Krachler, R., von der Kammer, F., Jirsa, F., Süphandag, A., Krachler, R. F., Plessl, C., Vogt, M., Keppler, B. K., and Hofmann, T.: Nanoscale lignin particles as sources of dissolved iron to the ocean: NANOSCALE LIGNIN PARTICLES, Global Biogeochem. Cy., 26, GB3024, https://doi.org/10.1029/2012GB004294, 2012.

Kritzberg, E. S. and Ekström, S. M.: Increasing iron concentrations in surface waters - a factor behind brownification?, Biogeosciences, 9, 1465-1478, https://doi.org/10.5194/bg-9-14652012, 2012.

Kurasaki, M., Hartoto, D. I., Saito, T., Suzuki-Kurasaki, M., and Iwakuma, T.: Metals in Water in the Central Kalimantan, Indonesia, B. Environ. Contam. Tox., 65, 591-597, https://doi.org/10.1007/s0012800164, 2000.

Lähteenoja, O., Ruokolainen, K., Schulman, L., and Oinonen, M.: Amazonian peatlands: an ignored $\mathrm{C}$ sink and potential source, Glob. Change Biol., 15, 2311-2320, https://doi.org/10.1111/j.1365-2486.2009.01920.x, 2009.

Lalonde, K., Vähätalo, A. V., and Gélinas, Y.: Revisiting the disappearance of terrestrial dissolved organic matter in the ocean: a $\delta^{13} \mathrm{C}$ study, Biogeosciences, 11, 3707-3719, https://doi.org/10.5194/bg-11-3707-2014, 2014.

Luciani, X., Mounier, S., Paraquetti, H. H. M., Redon, R., Lucas, Y., Bois, A., Lacerda, L. D., Raynaud, M., and Ripert, M.: Tracing of dissolved organic matter from the SEPETIBA Bay (Brazil) by PARAFAC analysis of total luminescence matrices, Mar. Environ. Res., 65, 148-157, https://doi.org/10.1016/j.marenvres.2007.09.004, 2008.

Luciani, X., Mounier, S., Redon, R., and Bois, A.: A simple correction method of inner filter effects affecting FEEM and its application to the PARAFAC decomposition, Chemom. Intell. Lab. Syst., 96, 227-238, https://doi.org/10.1016/j.chemolab.2009.02.008, 2009.

Martin, P., Cherukuru, N., Tan, A. S. Y., Sanwlani, N., Mujahid, A., and Müller, M.: Distribution and cycling of terrigenous dissolved organic carbon in peatland-draining rivers and coastal waters of Sarawak, Borneo, Biogeosciences, 15, 6847-6865, https://doi.org/10.5194/bg-15-6847-2018, 2018.

McKnight, D. M., Boyer, E. W., Westerhoff, P. K., Doran, P. T., Kulbe, T., and Andersen, D. T.: Spectrofluorometric characterization of dissolved organic matter for indication of precursor organic material and aromaticity, Limnol. Oceanogr., 46, 38-48, https://doi.org/10.4319/lo.2001.46.1.0038, 2001.

Miettinen, J., Hooijer, A., Vernimmen, R., Liew, S. C., and Page, S. E.: From carbon sink to carbon source: extensive peat oxidation in insular Southeast Asia since 1990, Environ. Res. Lett., 12, 024014, https://doi.org/10.1088/1748-9326/aa5b6f, 2017.

Moore, S., Gauci, V., Evans, C. D., and Page, S. E.: Fluvial organic carbon losses from a Bornean blackwater river, Biogeosciences, 8, 901-909, https://doi.org/10.5194/bg-8-901-2011, 2011.

Moore, S., Evans, C. D., Page, S. E., Garnett, M. H., Jones, T. G., Freeman, C., Hooijer, A., Wiltshire, A. J., Limin, S. H., and Gauci, V.: Deep instability of deforested tropical peatlands revealed by fluvial organic carbon fluxes, Nature, 493, 660-663, https://doi.org/10.1038/nature11818, 2013.

Müller, D., Warneke, T., Rixen, T., Müller, M., Jamahari, S., Denis, N., Mujahid, A., and Notholt, J.: Lateral carbon fluxes and $\mathrm{CO}_{2}$ outgassing from a tropical peat-draining river, Biogeosciences, 12, 5967-5979, https://doi.org/10.5194/bg-12-5967-2015, 2015. 
Neubauer, E., von der Kammer, F., Knorr, K.-H., Peiffer, S., Reichert, M., and Hofmann, T.: Colloid-associated export of arsenic in stream water during stormflow events, Chem. Geol., 352, 8191, https://doi.org/10.1016/j.chemgeo.2013.05.017, 2013.

Page, S. E., Rieley, J. O., and Wüst, R.: Chapter 7 Lowland tropical peatlands of Southeast Asia, Developments in Earth Surface Processes, 9, 145-172, https://doi.org/10.1016/S09282025(06)09007-9, 2006.

Page, S. E., Rieley, J. O., and Banks, C. J.: Global and regional importance of the tropical peatland carbon pool, Glob. Change Biol., 17, 798-818, https://doi.org/10.1111/j.13652486.2010.02279.x, 2011.

Palmer, S. M., Evans, C. D., Chapman, P. J., Burden, A., Jones, T. G., Allott, T. E. H., Evans, M. G., Moody, C. S., Worrall, F., and Holden, J.: Sporadic hotspots for physico-chemical retention of aquatic organic carbon: from peatland headwater source to sea, Aquat. Sci., 78, 491-504, https://doi.org/10.1007/s00027015-0448-x, 2016.

Pokrovsky, O. S., Dupré, B., and Schott, J.: Fe-Al-organic Colloids Control of Trace Elements in Peat Soil Solutions: Results of Ultrafiltration and Dialysis, Aquat. Geochem., 11, 241-278, https://doi.org/10.1007/s10498-004-4765-2, 2005.

Pokrovsky, O. S., Shirokova, L. S., Viers, J., Gordeev, V. V., Shevchenko, V. P., Chupakov, A. V., Vorobieva, T. Y., Candaudap, F., Causserand, C., Lanzanova, A., and Zouiten, C.: Fate of colloids during estuarine mixing in the Arctic, Ocean Sci., 10, 107-125, https://doi.org/10.5194/os-10-107-2014, 2014.

Pokrovsky, O. S., Manasypov, R. M., Loiko, S. V., and Shirokova, L. S.: Organic and organo-mineral colloids in discontinuous permafrost zone, Geochim. Cosmochim. Ac., 188, 1-20, https://doi.org/10.1016/j.gca.2016.05.035, 2016.

Poulin, B. A., Ryan, J. N., and Aiken, G. R.: Effects of Iron on Optical Properties of Dissolved Organic Matter, Environ. Sci. Technol., 48, 10098-10106, https://doi.org/10.1021/es502670r, 2014.

R Core Team: A language and environment for statistical computing, R Foundation for Statistical Computing, Vienna, Austria, available at: http://R-project.org/, last access: 30 June 2019.

Rixen, T., Baum, A., Pohlmann, T., Balzer, W., Samiaji, J., and Jose, C.: The Siak, a tropical black water river in central Sumatra on the verge of anoxia, Biogeochemistry, 90, 129-140, https://doi.org/10.1007/s10533-008-9239-y, 2008.

Rothwell, J. J., Evans, M. G., Daniels, S. M., and Allott, T. E. H.: Baseflow and stormflow metal concentrations in streams draining contaminated peat moorlands in the Peak District National Park (UK), J. Hydrol., 341, 90-104, https://doi.org/10.1016/j.jhydrol.2007.05.004, 2007.

Rothwell, J. J., Evans, M. G., Daniels, S. M., and Allott, T. E. H.: Peat soils as a source of lead contamination to upland fluvial systems, Environ. Pollut., 153, 582-589, https://doi.org/10.1016/j.envpol.2007.09.009, 2008.

Sharpless, C. M., Aeschbacher, M., Page, S. E., Wenk, J., Sander, M., and McNeill, K.: Photooxidation-Induced Changes in Optical, Electrochemical, and Photochemical Properties of Humic Substances, Environ. Sci. Technol., 48, 2688-2696, https://doi.org/10.1021/es403925g, 2014.

Spencer, R. G. M., Stubbins, A., Hernes, P. J., Baker, A., Mopper, K., Aufdenkampe, A. K., Dyda, R. Y., Mwamba, V. L., Mangangu, A. M., Wabakanghanzi, J. N., and Six, J.: Photochemical degradation of dissolved organic matter and dissolved lignin phenols from the Congo River, J. Geophys. Res.-Biogeo., 114, G03010, https://doi.org/10.1029/2009JG000968, 2009.

ThomasArrigo, L. K., Mikutta, C., Byrne, J., Barmettler, K., Kappler, A., and Kretzschmar, R.: Iron and Arsenic Speciation and Distribution in Organic Flocs from Streambeds of an ArsenicEnriched Peatland, Environ. Sci. Technol., 48, 13218-13228, https://doi.org/10.1021/es503550g, 2014.

Tipping, E., Rey-Castro, C., Bryan, S. E., and Hamilton-Taylor, $\mathrm{J} .: \mathrm{Al}(\mathrm{III})$ and $\mathrm{Fe}(\mathrm{III})$ binding by humic substances in freshwaters, and implications for trace metal speciation, Geochim. Cosmochim. Ac., 66, 3211-3224, https://doi.org/10.1016/S00167037(02)00930-4, 2002.

Valentine, B., Kamenov, G. D., and Krigbaum, J.: Reconstructing Neolithic groups in Sarawak, Malaysia through lead and strontium isotope analysis, J. Archaeol. Sci., 35, 1463-1473, https://doi.org/10.1016/j.jas.2007.10.016, 2008.

Weishaar, J. L., Aiken, G. R., Bergamaschi, B. A., Fram, M. S., Fujii, R., and Mopper, K.: Evaluation of Specific Ultraviolet Absorbance as an Indicator of the Chemical Composition and Reactivity of Dissolved Organic Carbon, Environ. Sci. Technol., 37, 4702-4708, https://doi.org/10.1021/es030360x, 2003.

Weiss, D., Shotyk, W., Rieley, J., Page, S., Gloor, M., Reese, S., and Martinez-Cortizas, A.: The geochemistry of major and selected trace elements in a forested peat bog, Kalimantan, SE Asia, and its implications for past atmospheric dust deposition, Geochim. Cosmochim. Ac., 66, 2307-2323, https://doi.org/10.1016/S0016-7037(02)00834-7, 2002.

Wickham, H.: ggplot2: Elegant Graphics for Data Analysis, Springer, 2016.

Wickham, H., François, R., Henry, L., and Müller, K.: dplyr: A Grammar of Data Manipulation, R package version 0.8.0.1, available at: https://CRAN.R-project.org/package=dplyr, last access: 30 June 2019.

Wickland, K. P., Aiken, G. R., Butler, K., Dornblaser, M. M., Spencer, R. G. M., and Striegl, R. G.: Biodegradability of dissolved organic carbon in the Yukon River and its tributaries: Seasonality and importance of inorganic nitrogen, Global Biogeochem. Cy., 26, GB0E03, https://doi.org/10.1029/2012GB004342, 2012.

Wit, F., Müller, D., Baum, A., Warneke, T., Pranowo, W. S., Müller, M., and Rixen, T.: The impact of disturbed peatlands on river outgassing in Southeast Asia, Nat. Commun., 6, 10155, https://doi.org/10.1038/ncomms10155, 2015.

Yamashita, Y., Jaffé, R., Maie, N., and Tanoue, E.: Assessing the dynamics of dissolved organic matter (DOM) in coastal environments by excitation emission matrix fluorescence and parallel factor analysis (EEM-PARAFAC), Limnol. Oceanogr., 53, 19001908, https://doi.org/10.4319/lo.2008.53.5.1900, 2008.

Zhang, X., Müller, M., Jiang, S., Wu, Y., Zhu, X., Mujahid, A., Zhu, Z., Muhamad, M. F., Sia, E. S. A., Jang, F. H. A., and Zhang, J.: Distribution and Flux of Dissolved Iron of the Rajang and Blackwater Rivers at Sarawak, Borneo, Biogeosciences Discuss., https://doi.org/10.5194/bg-2019-204, in review, 2019.

Zhou, Y., Martin, P., and Müller, M.: Composition and cycling of dissolved organic matter from tropical peatlands of coastal Sarawak, Borneo, revealed by fluorescence spectroscopy and parallel factor analysis, Biogeosciences, 16, 2733-2749, https://doi.org/10.5194/bg-16-2733-2019, 2019. 